\title{
Влияние элементов технологии возделывания винограда на урожай и КПД ФАР клона 337 сорта Каберне-Совиньон в условиях Западного предгорно-приморского района Крыма
}

\author{
Александр Павлович Дикань ${ }^{1}$, д-р с.-х. наук, професcop; alexdikan@mail.ru; \\ Домника Анатольевна Каширина², агроном, di-amante@yandex.ru \\ 1295492, Республика Крым, г. Симферополь, пгт Аграрное, ул. Спортивная, д.10, кв.38; \\ ${ }^{2}$ Республика Крым, Бахчисарайский район, с. Вилино, пер. Выгонный, 13, 000 «Инвест Плюс».
}

\begin{abstract}
Приводятся результаты трехлетних исследований по клону 337 сорта Каберне-Совиньон в Западном предгорно-приморском районе Крыма. Показано влияние различной нагрузки на куст $(11,17$ и 22 глазка) и зеленых операций (чеканка побегов, нормирование урожая, удаление листьев в зоне гроздей с восточной стороны) на величину урожая и коэффициент полезного действия (КПД) фотосинтетически активной радиации (ФАР). Установлено, что максимальная величина КПД ФАР была 0,52\% при нагрузке на куст в две лозы плодоношения без последующих зеленых операций. Изменение КПД ФАР на 93,4\% зависит от изменения площади листовой поверхности куста. Между КПД ФАР и урожаем винограда с куста существует сильная линейная корреляционная связь и регрессионная зависимость. Изменение массы урожая винограда с куста на 99,9\% зависит от изменения площади листовой поверхности куста и КПД ФАР. Увеличенная нагрузка до 17-22 глазков при обрезке будет способствовать наиболее рациональному использованию ресурсов продуктивности кустов клона 337 сорта Каберне-Совиньон в Западном предгорно-приморском районе Крыма.

Ключевые слова: виноград; клон сорта; нагрузка куста; КПД ФАР; площадь листьев; урожай; корреляционная связь и регрессионная зависимость.
\end{abstract}

The effect of grapevine cultivation technology elements on harvest and efficiency coefficient of photosynthetically active radiation of clone 337 of 'Cabernet Sauvignon' in the conditions of Western piedmont-coastal region of Crimea

\author{
Alexander Pavlovich Dikan¹, Domnica Anatolyevna Kashirina². \\ ${ }^{1}$ Agrarnoye, 10 Sportivnaya Str., apt. 38;
}

${ }^{2}$ Vilino, Republic of Crimea, OOO Invest Plus.

The paper summarizes results of a three-year study on clone 337 of 'Cabernet Sauvignon' cultivar in the western piedmont-coastal region of Crimea. The paper demonstrates the influence of various bush loads (11, 17 and 22 eyes) and green operations (shoot trimming, harvest regulation, leaf removal in the bunch area on the eastern side) on the yield size and efficiency coefficient of photosynthetically active radiation. It was found that the maximum efficiency of photosynthetically active radiation made $0.52 \%$ with the bush load of two fruiting canes without subsequent green operations. The $93.4 \%$ variance of the efficiency coefficient of photosynthetically active radiation is dependent on leaf surface area variations of the bush. There is a strong linear correlation and regressional relationship between the efficiency of photosynthetically active radiation and the yield of grapes per bush. The $99.9 \%$ increase of the yield per bush weight depends on the change in the leaf surface area of the bush and the efficiency coefficient of photosynthetically active radiation. Increasing the load up to 17-22 buds when pruning will contribute to the most rational use of bush productivity resources of clone 337 of 'Cabernet Sauvignon' in the western piedmont-coastal region of Crimea. Key words: vine; cultivar clone; bush load; efficiency coefficient of photosynthetically active radiation; leaf area; harvest; correlation and regressional dependence.
B ведение. Критериями продуктивности виноградника явцяются сырой урожай гроздей, массовая концентрация сахаров сока ягоА, сухая биомасса побегов и гроз-

\footnotetext{
Как цитировать эту статью:

Дикань А.П., Каширина Д.А. Влияние элементов технологии возделывания винограда на урожай и КПД ФАР клона 337 сорта Каберне-Совиньон в условиях западного предгорно-приморского района Крыма//«Магарач». Виноградарство и виноделие, 2019; 21(2); С. 117-121.

ноделие, 2019; 21(2); С. 117-121.

How to cite this article:

Dikan A.P., Kashirina D.A. The effect of grapevine cultivation technology elements on harvest and efficiency coefficient of photosynthetically active radiation of clone 337 of 'Cabernet Sauvignon' in the conditions of Western piedmont-coastal region of Crimea. Magarach. Viticulture and Winemaking, 2019; 21(2); pp. 117-121

DOI 10.35547/IM.2019.21.2.008
}

удК 634.85:631.524.82/.526.32(470.75)

Поступила 06.02.2019

Принята к публикации 16.05.2019

(C) Авторы, 2019
Аей; коэффициент использования энергии фотосинтетически активной радиации, поступающей на винограАник за возможный периоА вегетации [4]. Авойственная природа винограда (светолюбивость и одновременно теневыносливость), относительно невысокое световое насыщение фотосинтеза определяют то обстоятельство, что при высокой интенсивности оптического излучения коэффициенты поглощения его несколько ниже, чем при среАних и низких показателях [8].

Коэффициент полезного действия (КПА) фотосинтетически активной радиации (ФАР), отношение количества энергии, аккумулированной в биомассе урожая, к количеству поглощенной растениями фотосинтетически активной радиации за период накопления этой биомассы. Показывает, сколько процентов поглощенной световой энергии бымо запасено в форме энергии химических связей при превращении Аиоксида углерода в углеводы [3].

Эффективность использования ФАР еАиницей площади агроценоза оценивается по величине КПА падающей ФАР; в оптимацьных условиях КПА ФАР Аостигает 4-5\%. Эффективность использования поглощенной растениями ФАР на фотосинтез оценивается по величине КПА поглощенной ФАР; в среАнем за продукционный периоА она может достигать 6\% [9]. Амя отдельных Аистьев виноградного куста КПА ФАР при особо благоприятных условиях достигает $15 \%$. 
В действительности этот коэффициент значительно ниже и составцяет в среднем $0,5-1,5 \%$; в качестве оптимальных принимаются уровни, равные 2-3\%. Это позволяет реацизовать только 15-20\% потенциацьной продуктивности насаждений. АаАьнейшее совершенствование технологии возделывания винограда направлено на повышение КПА ФАР Ао 4-5\% [3].

Изменение способа ведения укрывных виноградников от шпалерного Ао бесшпацерного привело к более интенсивной работе мистового аппарата, что способствовацо увеличению как общей биомассы растений $\left(\mathrm{У}_{\text {бион. }}\right)$, так и хозяйственно полезной ее части $\left(\mathrm{Y}_{\text {хоз. }}\right)$. При этом резко возросла степень использования падающей на растения солнечной радиации - КПА ФАР. Отмечено, что с ростом нагрузки с 44 Ао 67 тыс. побегов на один гектар в чашевидных насаждениях индустриального типа возрастали показатели биологического и хозяйственного урожая, а также чистая продуктивность и КПА ФАР [7]. Отмечено, что с ростом нагрузки с 44 до 67 тыс. побегов на один гектар в чашевидных насаждениях индустриального типа возрастали показатели биологического и хозяйственного урожая, а также чистая продуктивность и КПА ФAP [6].

Цемью работы было выявление наиболее оптимальной нагрузки кустов глазками и побегами при разцичных зеленых операциях Аля получения максимацьного КПА ФАР в загущенных насаждениях кмона 337 сорта Каберне-Совиньон в Западном предгорно-приморском природно-виноградарском районе Крыма.

Место и методика исследований. Опыт был проведен в 2015-2017 гг. на клоне 337 сорта Каберне-Совиньон на виноградниках ООО «Инвест пцюс» в с. Песчаное Бахчисарайского района Республики Крым.

Посадка была выполнена весной 2010 г.

Схема посадки кустов 2,5 x 1,0 м. Форма кустов - однопмечий Гюйо. ПоАвойный сорт Берландиери х Рипариа Кобер 5 ББ. Шпалера вертикацьная, Авухметровая. На участке применяется капельное орошение.

Почва на участке - чернозем южный мицелярнокарбонатный.

КАимат района - засушиивый, умеренно-жаркий, с мягкой зимой.

Среднегодовая температура воздуха (по метеостанции «Евпатория» $[1])$ равняется $+10,2 \ldots+11,4^{\circ} \mathrm{C}$. Самый теплый месяц - июль, со среАней температурой воздуха $+23,7^{\circ} \mathrm{C}$, а самый холодный месяц - февраль $\left(-0,5^{\circ} \mathrm{C}\right)$. Средний из абсолютных минимумов температуры воздуха достигает $-16^{\circ} \mathrm{C}$, абсолютный минимум - $-28^{\circ} \mathrm{C}[12]$. Сумма активных температур воздуха составляет $3625^{\circ} \mathrm{C}$. Среднее количество осадков равняется 374 мм.

По Аанным радиометеостанции, установленной на винограднике, погодные условия 2015 г. характеризовались Аостаточным количеством осаАков - 476,8 мм. Сумма активных температур составика $-3811^{\circ} \mathrm{C}$. В 2016 г. осадков выпало значительно меньше - 394,4 мм, сумма активных температур составцяна $3261^{\circ} \mathrm{C}$. В 2017 г. осаАки равнялись 505,6 мм, активные температуры $-3445^{\circ} \mathrm{C}$.
Изучалось влияние различной нагрузки глазками и размичных зеленых операций на урожай и КПА ФАР, поступающей на виноградник за период вегетации. Расчет величины урожая и значений КПА ФАР проводились по общепринятым методикам $[2,4]$.

\section{Варианты опыта:}

\begin{tabular}{|c|c|}
\hline 1 & $\begin{array}{l}\text { - одна моза плодоношения (11 глазков), зеленые } \\
\text { операции (чеканка побегов, удамение мистьев } \\
\text { с восточной стороны кустов, нормирование } \\
\text { урожая); }\end{array}$ \\
\hline 2 & 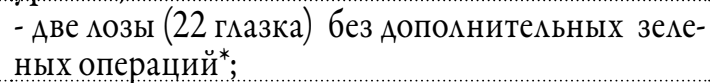 \\
\hline 3 & 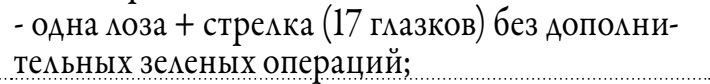 \\
\hline 4 & - Аве мозы (22 глазка), чеканка побегов; \\
\hline 5 & 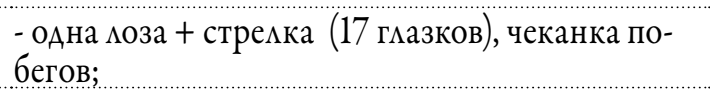 \\
\hline $\begin{array}{l}6 \\
(\text { контроль) }\end{array}$ & $\begin{array}{l}\text { - одна моза (11 гмазков) без дополнитемьных зе- } \\
\text { меных операций; }\end{array}$ \\
\hline 7 & - одна моза (11 глазков), нормирование урожая; \\
\hline 8 & - одна моза (11 глазков), чеканка побегов; \\
\hline 9 & 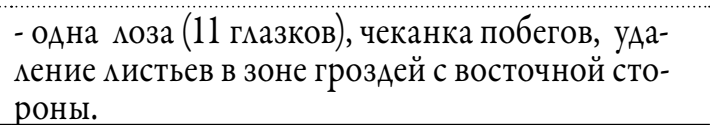 \\
\hline
\end{tabular}

* проводимись обязатемьные зеленые операции, такие как обломка побегов на штамбе, обломка Авойников, заведение зеленых побегов за спаренные проволоки шпалеры, а дополнительные, т.е. чеканка побегов, нормирование урожая, удаяение $\Lambda$ истьев не применя $и$ иь.

Нагрузка в побегах за годы исследований составика:

в первом варианте 10,2 шт./куст, во втором - 18,8 шт./куст; в третьем - 14,8 шт./куст; в четвертом 19,2 шт./куст; в пятом - 14,9 шт./куст; в шестом (к) - 10,1 шт./куст; в сеАьмом - 10,2 шт./куст; восьмом - 10,1 шт./куст; в девятом - 10,1 шт./куст $\left(\mathrm{HCP}_{05}=\right.$ 0,97 побегов/куст).

Результаты исследований. Аанные по продуктивности винограда по кмону 337 сорта Каберне-Совиньон представлены в таблице. Пмощадь Аистовой поверхности изменялась от $2,22 \mathrm{~m}^{2} /$ куст в первом варианте до $5,98 \mathrm{~m}^{2} /$ куст - во втором варианте. Существенно больше, чем в контроле, были данные во втором-четвертом вариантах. Такое колебание вели-

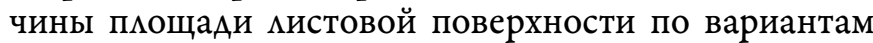
объясняется увеличенным количеством глазков, а затем побегов, оставценных на кустах во втором-пятом вариантах. Также кусты в вариантах с применением чеканки (первый, четвертый, пятый, восьмой и Аевя-

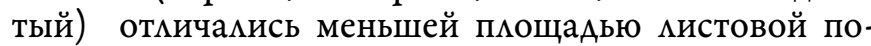
верхности от вариантов с меньшим количеством агротехнических приемов.

Урожай с куста и урожайность с гектара были минимацьными в первом и седьмом вариантах, что связано с дополнительным нормированием и удалением урожая в этих вариантах, максимацьными эти показатели были во втором варианте (3,24 кг/куст и 12,96 т/га соответственно). Урожайность была высокой и в остальных вариантах с увеличенной нагрузкой: 11,88 т/га (пятый вариант); 11,96 т/га (третий вариант) и 
Таблица. КПД ФАР и урожай винограда клона 337 сорта Каберне-Совиньон

Table 1. Efficiency coefficient of photosynthetically active radiation and yield of clone 337 of 'Cabernet Sauvignon' cultivar

\begin{tabular}{|c|c|c|c|c|c|c|c|}
\hline Вариант & 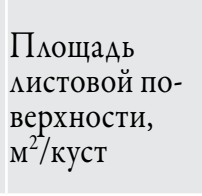 & $\begin{array}{l}\text { Урожай, } \\
\text { кг/куст }\end{array}$ & $\begin{array}{l}\text { УАемьная хозяй- } \\
\text { ственная продук- } \\
\text { тивность Аця сы- } \\
\text { рой массы грозАей, } \\
\text { кг/м² }\end{array}$ & $\begin{array}{l}\text { Урожай- } \\
\text { ность, } \\
\text { т/га }\end{array}$ & $\begin{array}{l}\text { Сухая масса } \\
\text { хозяйственно- } \\
\text { го урожая, } \\
\text { т }\end{array}$ & $\begin{array}{l}\text { Сухая масса } \\
\text { биологиче- } \\
\text { ского урожая, } \\
\text { т }\end{array}$ & $\underset{\%}{\text { КПА ФАР, }}$ \\
\hline 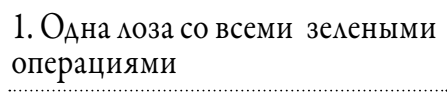 & 2,22 & $1,53^{*}$ & 0,69 & $6,12^{*}$ & 1,22 & 2,44 & 0,24 \\
\hline $\begin{array}{l}\text { 2. Аве мозы, без Аопомнитель- } \\
\text { ных зеленых операций }\end{array}$ & $5,98^{*}$ & $3,24^{*}$ & 0,54 & $12,96^{*}$ & 2,59 & 5,18 & 0,52 \\
\hline $\begin{array}{l}\text { 3. ОАна моза + стремка, без Ао- } \\
\text { полнитемьных зеленых опера- } \\
\text { ций }\end{array}$ & $5,10^{*}$ & $2,99^{*}$ & 0,59 & $11,96^{*}$ & 2,39 & 4,78 & 0,48 \\
\hline 4. Аве мозы + чеканка & $4,65^{*}$ & $3,06^{*}$ & 0,66 & $12,24^{*}$ & 2,45 & 4,90 & 0,49 \\
\hline 5. ОАна $о$ оза + стрелка, чеканка & 4,01 & $2,97^{*}$ & 0,74 & $11,88^{*}$ & 2,38 & 4,76 & 0,48 \\
\hline $\begin{array}{l}\text { 6. ОАна моза без Аополнитель- } \\
\text { ных зеленых операций } \\
\text { (контроль) }\end{array}$ & 3,07 & 2,07 & 0,67 & 8,28 & 1,66 & 3,32 & 0,33 \\
\hline $\begin{array}{l}\text { 7. ОАна моза + нормирование } \\
\text { урожая }\end{array}$ & 3,36 & $1,53^{*}$ & 0,46 & $6,12^{*}$ & 1,22 & 2,44 & 0,24 \\
\hline 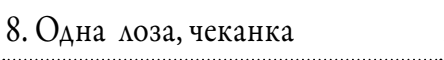 & 2,75 & 2,16 & 0,79 & 8,64 & 1,73 & 3,46 & 0,35 \\
\hline $\begin{array}{l}\text { 9. ОАна } \Lambda \text { оа + чеканка + уда- } \\
\text { мение } \Lambda \text { истьев в зоне гроздей с } \\
\text { восточной стороны }\end{array}$ & 2,31 & 2,25 & 0,97 & 9,00 & 1,80 & 3,60 & 0,36 \\
\hline $\mathrm{HCP}_{05}$ & 0,96 & 0,39 & - & 1,57 & - & - & - \\
\hline
\end{tabular}

*- существенное размичие с контролем

12,24 т/га (четвертый вариант) и 12,96 т/ га (второй вариант).

Массовая концентрация сахаров в соке ягод составила: в первом варианте - 247 г/Ам ${ }^{3}$ (массовая концентрация титруемых кислот - 6,9 г/Ам $\left.{ }^{3}\right)$; во втором, третьем, четвертом и пятом вариантах $230(7,6) ; 230(7,5) ; 225(7,6)$ и 227 г/ $\mathrm{AM}^{3}$ $\left(7,6\right.$ г/Ам $\left.{ }^{3}\right)$. Результаты мабораторных исследований в контрольном варианте показали массовую концентрацию сахаров в количестве 236 г/Ам ${ }^{3}$, а титруемых кис-

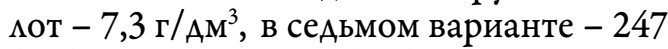
$(7,2)$, восьмом - $236(7,3)$, Аевятом - 239 $\left(7,2\right.$ г/Ам $\left.{ }^{3}\right)$. Минимальным показатель массовой концентрации сахаров быц в четвертом варианте - 225236 г/ AM $^{3}$; максимальным - 247 г/Ам ${ }^{3}$ - в первом и седьмом вариантах. Массовая концентрация сахаров и титруемых кислот соответствоваца ГОСТ 31782-2012 [5].

КПА ФАР рассчитывался согласно методике [3], через расчёт сухой массы хозяйственного урожая и сухой массы биологического урожая. Графическое выражение Аинамики КПА ФАР преАставцено на рис. 1. КПА ФАР у кмона 337 сорта Каберне-Совиньон в среднем за 2015-2017 гг. значительно отмичался по

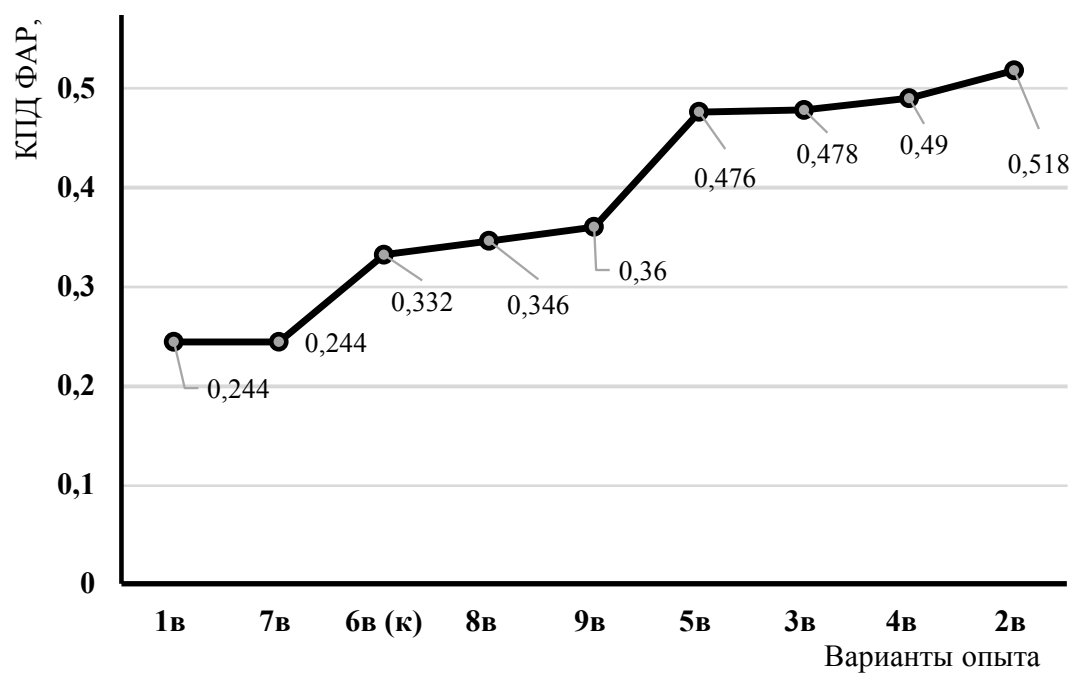

Рис. 1. Изменения КПД ФАР у клона 337 сорта Каберне-Совиньон по вариантам опыта.

Fig. 1. Efficiency coefficient variations of photosynthetically active radiation of clone 337 of 'Cabernet Sauvignon' cultivar by trial variants

вариантам. Наименьшим этот показатель $(0,24 \%)$ бым в первом варианте, с применением всего комплекса дополнительных земеных операций, и в седьмом варианте, где бымо нормирование урожая (табл.). Выше значения КПА ФАР были в шестом (контроль), восьмом и девятом вариантах: 0,$33 ; 0,35$ и $0,36 \%$ соответственно. Еще выше КПА ФАР $(0,48 \%)$ бым в третьем и пятом вариантах, а также - в четвертом и втором $(0,49 ; 0,52 \%)$, гАе применялась увеличенная нагрузка. 
The effect of grapevine cultivation technology elements on harvest and efficiency coefficient of photosynthetically active radiation ...

МежАу иистовой поверхностью кустов $\left(\mathrm{M}^{2} /\right.$ куст, $\left.\mathrm{x}\right)$ и КПА ФАР $(\%, \mathrm{y})$ существует сильная минейная корреляционная связь и регрессионная зависимость (рис. 2). Величина корреляции, которая указывает на то, что связь была близка к функциональной, составцяет 0,969. Изменение КПА ФАР на 93,9\% зависит от изменения площади мистовой поверхности куста. Уравнение регрессии имело выражение $\mathrm{y}=0,0376 \mathrm{x}+0,1996$. Следует отметить невысокий коэффициент регрессии, указывающий на то, что КПА ФАР в связи с увеличением Аистовой поверхности на $1 \mathrm{~m}^{2}$ будет возрастать на $0,0376 \%$.

Изучение связи межАУ КПА ФАР $(\%, \mathrm{~m})$ и урожаем винограАа (кг/куст, к) показало, что межАу факторами также существует сильная цинейная корреляционная связь и регрессионная зависимость (рис. 3). Корреляционная связь равняется 0,970. Изменение урожая с куста на 97,0\% зависит от изменения КПА ФАР. Уравнение, показывающее величину урожая винограда с куста (кг/куст, к) в связи с изменением КПА ФАР (\%, m), имеет виА К $=0,2347 \mathrm{~m}+1,2489$.

Быма также найдена множественная Аинейная корреляционная связь и регрессионная зависимость межАу тремя переменными: кистовой поверхностью $\left(\mathrm{m}^{2} /\right.$ куст, с), КПА ФАР (\%, z) и урожаем винограда (кг/куст, d) у изучаемого клона (рис. 4). Коэффициент множественной корреляции равнялся 0,999, коэффициент множественной детерминации также равнялся 0,999. ПослеАняя величина показывает, что на 99,9\% изменение урожая винограда зависит от изменения этих Авух переменных факторов, т.е. площади мистовой поверхности куста и КПА ФАР. При этом уравнение регрессии было следующим $d=0,005949+0,003277 c+6,203226 z$. Как виАно, коэффициент частной регрессии при «z» очень высокий и при изменении даже на 0,1\% КПА ФАР (при неизменном параметре «с») урожай с куста увеличится на 620 г/куст, что приведет к возрастанию урожайности на 24,8 ц/га.

Заключение. В загущенных насажАениях изучаемых Аевяти вариантов кмона 337 сорта Каберне-Совиньон в Западном предгорно-приморском районе Крыма в 2015-2017 гг. было установмено следующее.

$\Lambda$ истовая поверхность на кустах изменялась от 2,22 до 5,98 м², что привело к формированию урожая на кустах от 1,53 Ао 3,24 кг или от 6,12 до 12,96 т/га.

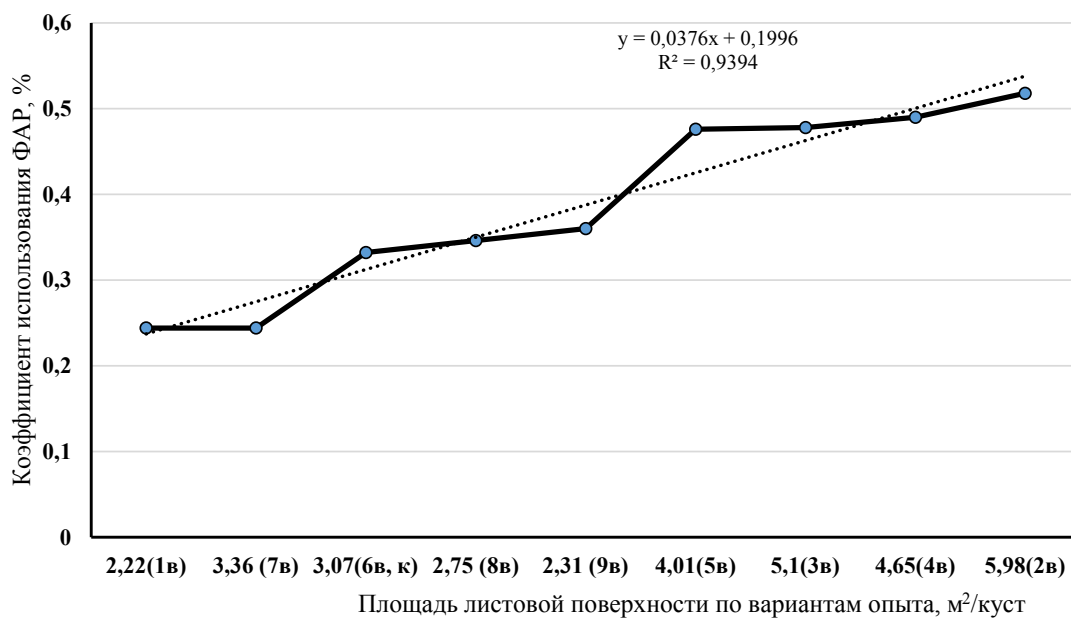

Рис. 2. Зависимость между площадью листовой поверхности $\left(\mathrm{M}^{2} / \mathrm{kycт,} \mathrm{x}\right)$ и КПД ФАР (\%, у) у клона 337 сорта Каберне-Совиньон.

Fig. 2. Correlation between leaf surface area (m2/bush, $x)$ and efficiency coefficient of photosynthetically active radiation (\%,y) of clone 337 of 'Cabernet Sauvignon' cultivar.

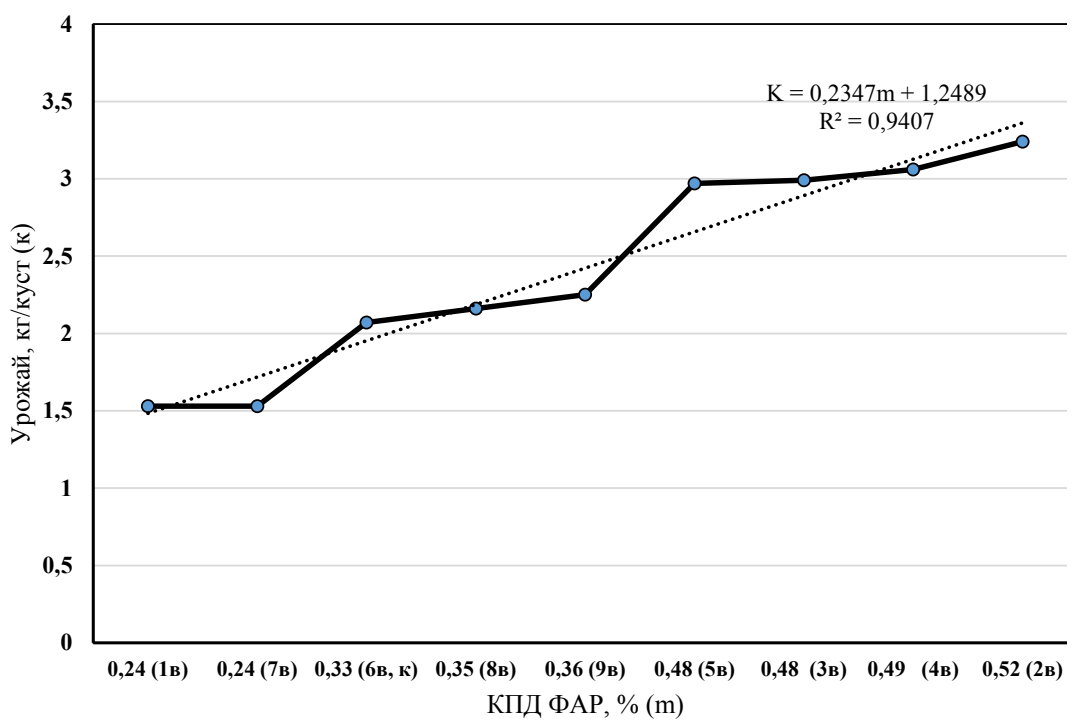

Рис. 3. Зависимость между КПД ФАР (\%, m) и урожаем винограда (кг/куст, к) у клона 337 сорта Каберне-Совиньон.

Fig. 3. Correlation between efficiency coefficient of photosynthetically active radiation $(\%, \mathrm{~m})$ and grape harvest ( $\mathrm{kg} / \mathrm{bush}, \mathrm{k}$ ) of clone 337 of 'Cabernet Sauvignon' cultivar

При этом удельная хозяйственная продуктивность Аля сырой массы гроздей изменялась в пределах 0,46-0,97 кг/м².

КПА ФАР быц минимальным с нагрузкой на куст по одной мозе

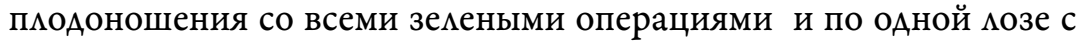
нормированием урожая, состав яя $0,24 \%$. Максимальная величина КПА ФАР быма 0,52\% при нагрузке на куст в Аве Аозы плодоношения без последующих дополнительных зеленых операций.

Изменение КПА ФАР на 93,94\% зависит от изменения пмощади Аистовой поверхности куста. МежАу КПА ФАР и урожаем винограда с куста существует симьная Аинейная корреляционная связь и регрессионная зависимость. Изменение урожая с куста на 94,07\% зависит от изменения КПА ФАР. МежАу мистовой поверхностью куста, КПА ФАР, урожаем винограда с куста существует симьная множественная минейная корреляционная связь и регрессионная зависимость. Изменение массы урожая винограда с куста на 99,9\% зависит от изменения площади мистовой поверхности куста и КПА ФАР.

Увемиченная нагрузка Ао 17-22 глазков при обрезке будет спо- 
собствовать наиболее рационацьному использованию ресурсов продуктивности кустов кмона 337 сорта Каберне-Совиньон в ЗапаАном предгорно-приморском районе Крыма. Наиболее целесообразными явцяются варианты с увемичением нагрузки глазками при обрезке Ао 17 и 22 глазков с чеканкой и без нее. При высоком уровне агротехники применяемая нагрузка позвоцит получать высокие качественные урожаи, соответствующие ГОСТ 31782-2012.

\section{Источник финансирования}

Не указан.

\section{Financing source}

Not specified.

\section{Конфликт интересов}

Не заявлен.

\section{Conflict of interests} Not declared.

\section{Список литературы / References}

1. Агроклиматический справочник по Крымской области. - Л.: Гидрометеоиздат, 1959. - 135 с.

Agroklimaticheskiy spravochnik po Krymskoy oblasti [Agroclimatic guide to the Crimean region] Leningrad: Gidrometeoizdat [Leningrad: Gidrometeoizdat], 1959. p. 135. (in Russian)

2. Агротехнические исследования по созданию интенсивных виноградных насаждений на промышленной основе / Е.И. Захарова, [и др.]: под. ред. Б.А. Музыченко. - Новочеркасск, 1978. - 177 с.

Agrotekbnicheskiye issledovaniya po sozdaniyu intensivnykh vinogradnykh nasazhdeniy na promyshlennoy osnove / Ye.I. Zakharova, [i dr.]: pod. red. B.A. Muzychenko [Agrotechnical studies on establishment of intensive vineyards on a commercial basis / E. I. Zakharova [et al.]: under. ed. by B. A. Muzychenko]. - Novocherkassk, 1978. - 177 p. (in Russian)

3. Амирджанов, А. Г. Солнечная радиация и продуктивность виноградника / А.Г. Амирджанов. - Л., 2000.

Amirdzhanov A. G. Solnechnaya radiatsiva i produktivnost' vinogradnika [Solar radiation and productivity of a vineyard]. Leningrad, 2000. (in Russian)

4. Амирджанов, А.Г. Прогнозирование и программирование урожаев винограда (методические рекомендации) / А. Г. Амирджанов. - Ялта, 1988. -108 c.

Amirdzhanov A.G. Prognozirovanive $i$ programmirovaniye urozhayev vinograda (metodicheskiye rekomendatsii) [Forecasting and programming of grape harvests (guidelines)]. Yalta, 1988. 108 p. (in Russian)

5. ГОСТ 31782-2012 Виноград свежий машинной и ручной уборки для промышленной переработки. Технические условия. [Электронный ресурс]. - Режим доступа: http://docs.cntd.ru/ document/1200101151.

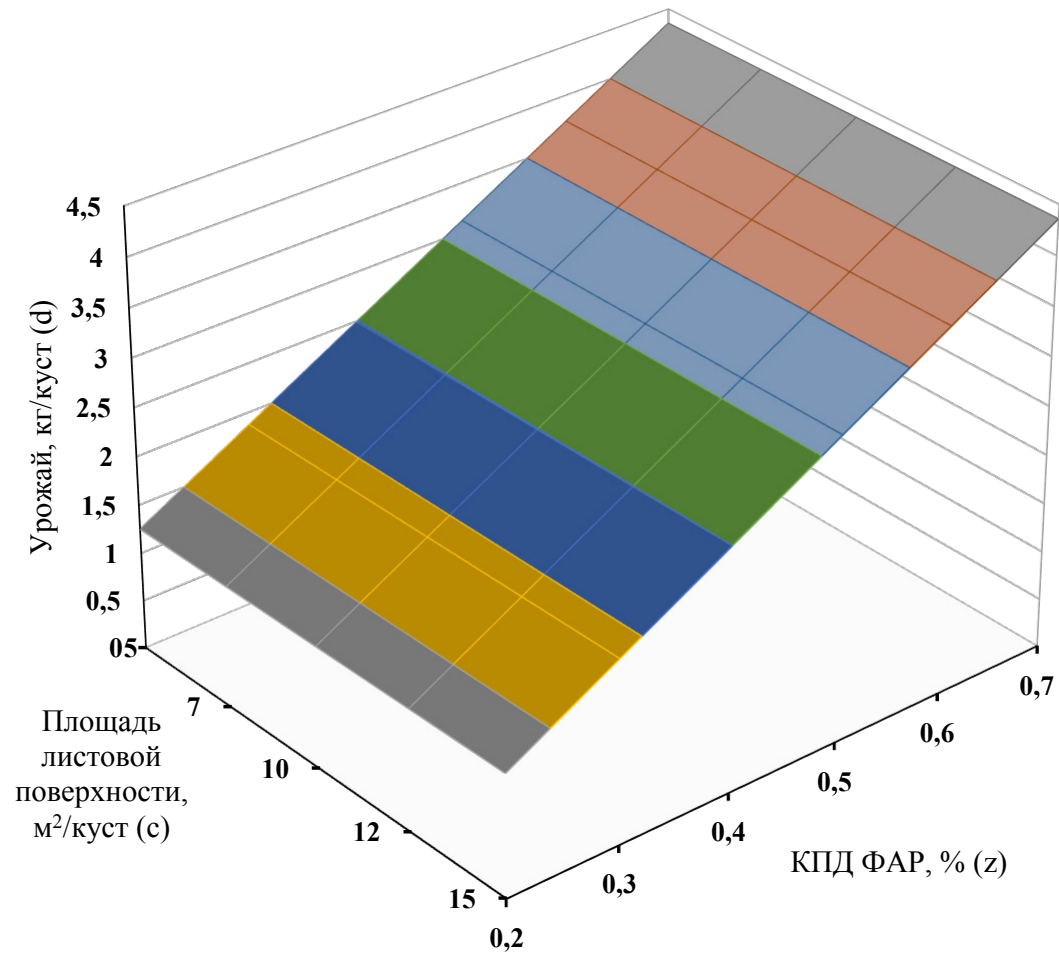

Рис. 4. Зависимость урожая винограда клона 337 сорта Каберне-Совиньон (кг/куст, d) от совместного действия площади листовой поверхности куста $\left(\mathrm{M}^{2} /\right.$ куст, с) и КПД ФАР $(\%, z)$.

Fig. 4. Correlation between the yield of clone 337 of 'Cabernet Sauvignon' cultivar (kg/bush, d) and cumulative effect of leaf surface area ( $\left.\mathrm{m}^{2} / \mathrm{bush}, \mathrm{c}\right)$, and efficiency coefficient of photosynthetically active radiation $(\%, \mathrm{z})$

GOST 31782-2012 Vinograd svezhiy mashinnoy i ruchnoy uborki dlya promyshlennoy pererabotki. Tekbnicheskiye usloviya. [Elektronnyy resurs]. - Rezhim dostupa: bttp:// docs.cntd.ru/document/1200101151 [GOST 31782-2012 Grapes fresh machine and manual cleaning for industrial processing. Technical conditions. [Electronic resource.] Mode of access: http://docs.cntd.ru/document/1200101151] (in Russian)

6. Гусейнов, Ш.Н.. Облиственность и продуктивность фотосинтеза насаждений при различных способах ведения и формирования кустов винограда / Ш.Н. Гусейнов, С.В. Майбородин. Режим доступа - http://rusvine. $\mathrm{ru} /$-ш-н-гусейнов-с-в-майбородин-облиствен/

Guseynov SH.N, Mayborodin S.V. Oblistvennost' i produktionost' fotosinteza nasazhdeniy pri razlichnykh sposobakh vedeniya i formirovaniya kustov vinograda. Rezhim dostupa - http://rusvine.ru/sh-n-guseynov-s-v-mayborodin-oblistven/ [Huseynov Sh. N., Mayborodin S. V. leaf formation and photosynthetic productivity of plantations with different vine training. Access mode - http://rusvine.ru/ш-н-гусейновс-в-майбородин-облиствен/] (in Russian)

7. Гусейнов, Ш. Н. Прошлое и настоящее в способах ведения укрывных виноградников. - Электронный ресурс. - Режим доступа - http://rusvine.ru/ гусейнов-ш-н-прошлое-и-настоящее-в-спос/.

Guseynov SH.N. Proshloye i nastoyashcheye v sposobakh vedeniya ukryvnkh vinogradnikov. - Elektronnyy resurs. - Rezhim dostupa - bttp://rusvine.ru/guseynov-sh-nproshloye-i-nastoyashcheye- $v$-spos/ [Electronic resource]. (in Russian)

8. Смирнов, К. В. Виноградарство / К. В. Смирнов, Т.И. Калмыкова, Г.С. Морозова. М.: Агропромиздат, 1987. - 367 с.

Smirnov K. V., Kalmykova T.I., Morozova G.S. Vinogradarstvo [Viticulture]. Moscow: Agropromizdat, 1987. P. 367. (in Russian)

9. Тооминг Х. Г., Гуляев Б. И. Методика измерения фотосинтетически активной радиации. - М.: Наука, 1967 - 142 с.

Tooming X. G., Gulyayev B. I. Metodika izmereniya fotosinteticheski aktionoy radiatsii. Moscow: Science, 1967 p. 142. (in Russian) 